\title{
Do Customers All Respond The Same? Generational Differences on Customer Orientation and Satisfaction.
}

\author{
Karen Flaherty \\ (Ph.D., University of Massachusetts at Amherst) \\ Associate Professor of Marketing and \\ William S. Spears Chair in Business \\ Oklahoma State University \\ Michael Korir \\ (Ph. D, Kenyatta University) \\ Associate Professor of Strategic Management \\ and Director of Quality Assurance \\ Moi University, KENYA \\ Diane Chelangat \\ (Ph. D, Moi University) \\ Assistant Professor of Marketing \\ Moi University, KENYA
}

\begin{abstract}
Organisations have improved customer satisfaction by being customer oriented in all levels. At the firm level, organisations seek to develop customer oriented organization by generating market intelligence regarding the needs of the customer and disseminating the intelligence across departments that will lead to organization wide responsiveness to it. At an individual level, organisations seek to recruit and train employees to exhibit customer orientation behaviour. This study focuses on customer level of responsiveness to persuasion from customer oriented employees and also existence of different levels of satisfaction among three generational cohort groups (Baby Boomers, Generation $X$ and Generation $Y$ ). This study found generational differences on responsiveness hence pointing towards managers to develop products addressing different generations.
\end{abstract}

Physical goods are preproduced in a factory, whereas services are produced in a process in which consumers interact with the production resources of the service firm. Some part of the service may be prepared before the customers enter the process and the evaluation of the service happens at the point of contact. This highlights the importance of service organisations to focus their resources towards the point where there is an interaction between the customer, the employee and the service being offered.

Prior research clearly suggests that focusing on customer needs like customer orientation is important at firm level, individual level and customer level. Thus, it is not surprising that many service organizations pursue a market orientation. At the firm level, organisations seek to develop a customer orientation, which is the central element of a market orientation, through organization wide generation of market intelligence pertaining to current and future customer needs, dissemination of the intelligence across departments, and organization wide responsiveness to it (Kohli and Jaworski 1990). Brady and Cronin (2001) ascertained that being customer oriented allows firms to acquire and assimilate the information necessary to design and execute marketing strategies that result in more favorable customer outcomes. 
At an individual level, organisations seek to recruit and train employees to exhibit a customer orientation. Employees who use the most effective, or authentic, emotions while focusing on customer needs during service encounters are thought to present a high customer orientation (Brach et al., 2013). Essentially, frontline employees who are customer oriented, intrinsically enjoy meeting customer needs. Customer contact employees are likely to prioritize their actions in favor of providing customer benefits because customer orientation is positively related to outcomes such as performance and customer satisfaction (Boles et al., 2001).

A large body of research shows that customers with a higher level of satisfaction have higher levels of support behaviors such as repurchase, recommendation, cross buying, positive word of mouth, lower price elasticity, and longer relationship duration (Pallas 2014; Mittal and Frennea 2010), indicate relationships between expectations and emotions (Machleit and Eroglu 2000). Customers often notice employee effort exerted during service encounters and it leads to satisfaction across a variety of service industries (Mohr and Bitner 1995).

Since customer satisfaction reflects the degree of a customer's positive feeling for a service, it is important for service providers to understand the customer's vision of their services (Deng et al. 2010). Organisations strive to know categories of customers well and therefore segment them according to their generational cohort.

A definition of cohort by Parry and Urwin (2011) is solely based on birth years, whereas generations are determined by differences in values and attitudes that demarcate different birth groups. Generational cohorts are premised on the notion that shared experiences of individuals coming of age in a particular historical and social milieu shapes the unique identity of each generational cohort (Gardiner, Grace and King 2013; Schuman and Scott 1989; Mannhiem 1952). Furthermore, influence of social, political and cultural environments on individuals' values and attitudes (Leuty and Hansen 2014) also demarcate the groups. As a generation matures, it develops characteristics that differentiate it from previous generations (Bolton et al., 2013; Smola and Sutton, 2002). A functional link between the shared experiences and hence responses to attention induced by emotion has also been supported at the behavioral level by several psychophysical studies, (Pourtois et al., 2013; Bocanegra and Zeelenberg 2009,2011; Brosch et al., 2010; Phelps et al., 2006). The dynamic nature of generational cohorts therefore challenges marketers who seek to remain at the forefront of changing demographics and consumer trends that influence each generation's consumer behavior and its outcomes. Understanding the alignment between a consumer's self-identity and their respective generational stereotypical identity is important for effective marketing strategies that employ generational cohorts as a strategy for market segmentation (Gardiner, Grace and King 2013).

Although there is evidence in the literature regarding the influence of customer orientation on several outcomes in firm level, individual level and customer level, and evaluation of a service from customer's perception is different for all levels. Kruger and Dunning (1999) demonstrated that in a daily life context, competent individuals tend to overestimate their performance while incompetent individuals tend to underestimate it. Past studies indicate disparities on what constitutes a satisfactory service between the perceptions of the employee and the customer due to employee over confidence when rating their performance.

Customer's expectation of a satisfactory service and the level of response to persuasion through customer orientation efforts among generation cohort is a matter that should not be taken lightly by organisations that are at the forefront to satisfy their customers. Literature that may guide a prediction regarding generational cohort differences in their response to 
persuasion is limited to general characterization of the generational cohort groups. This research therefore attempted to fill the gap by finding out if generational cohort responds to persuasion from customer oriented employees and also if level of satisfaction differ among the three groups.

The concept and determinants of customer satisfaction being a function of a consumer's experiences, calls for analysis of large number of factors such reactions to a service provider's behavior during the service encounter, as well as a function of the service setting among others (Veloutsou et al., 2005; Nicholls et al., 1998). It is beyond the scope of this study to analyse these variables.

\section{CONCEPTUAL DEVELOPMENT}

This study, taking a marketing perspective concentrated on the levels of responsiveness towards persuasion from customer oriented employees and the difference of levels of satisfaction, in the perspective of the customer whose attitudes, values and beliefs vary across generations.

\section{Customer Orientation}

Customer orientation enhances an understanding of customers, and helps organisations design new or improved service solutions to meet customer needs (Tang 2014; Grissemann et al., 2013; Sin et al., 2005). A lot of research and literature have pointed out the importance of customer orientation in an organisation. Extant literature on customer orientation has pointed out the existence of dimensions of customer orientation. This study uses three dimensions: company commitment, customer commitment and customer experience.

Customer orientation from a customer's perspective is the extent to which customers believe that the service provider is committed to understanding and meeting their needs (Brach et al., 2013; Dean 2007). Company commitment and customer focus have become key words for businesses to succeed in the competitive market place, thus a customer oriented business culture is preferable for firms that seek success in the market (for example, Kim 2009; Parasuraman 1987; Houston 1986). These firms pay close attention to customers to meet their needs and wants (Valenzuela et al., 2010). Service employees' customer orientation, reflects their attitudes and predispositions to meet customer needs on the job (Brown et al., 2002; Harber and Fried 1975), has been identified as a key driver of customer outcomes, such as satisfaction (Jean et al 2016; Dean 2007; Hennig-Thurau 2004; Goff et al., 1997).

Another dimension of customer orientation is customer commitment. The customers themselves are important resources in the service process in which they should know their role in the system. The four parts of the interactive system, including the customer as one part, have an impact on each other. For example, the systems and the physical resources used have a direct influence on the quality perception of customers, as have the attitudes and behaviors of the contact personnel (Grönroos 1998; Lehtinen 1983). Sometimes customer oriented employees perform according to the expectations of customers and the way they are trained, but customers may create problems by not fulfilling their roles in the process, for instance not coming to appointments on time, not reading instructions, and not providing the required information to the service provider (Parasuraman et al., 1992). The effectiveness of customer orientation behaviors majorly depend on the situation of the purchase.

Customer orientation as an important element, employees do not necessarily behave the same way across customers and situations, and customers may respond in different ways to similar 
patterns of employee behaviors because of their different interests, needs, or capabilities (Delcourt et al., 2013). Therefore the differences in interest make their level of responsiveness to persuasion to differ across the generational cohort.

\section{Customer Satisfaction}

Customer satisfaction has attracted the most attention from both practitioners and researchers (Chen et al., 2014). For more than two decades, customer satisfaction has been an intensively discussed subject in the areas of consumer and marketing research. Customer satisfaction is a central construct in marketing research (Luo and Homburg 2007). Achieving customer satisfaction is the primary goal for most service firms today (Jones and Sasser 1995) as it benefits the firms when they provide satisfactory services to their customers (Kim 2009) since satisfaction is the main source of attracting customers (Patterson et al., 1997) and the most important source of gaining competitive advantage for service organisations (Zafar et a.l, 2012; Zeithaml et al., 1996; Bolton and Drew 1991; Parasuraman et al., 1991, 1988).

\section{Generational Cohort}

Generational cohort is a common tool for consumer market segmentation in marketing, which is used to target different groups of customers better (Arsenault 2004). This study adopted the birth years commonly found in most generational literature which the population can be divided into four cohorts based on generation: the Silent Generation (born between 1925 and 1942); the Baby Boomers (born between 1943 and 1960); Generation X (born between 1961 and 1981); and Generation Y (born between 1982 and 2000), (Strauss and Howe 1997). Though, generational cohort have an affective experience which reflects an underlying attribution of causal agency to eliciting stimulus to the individual self, involve an assignment of causal agency neither to the stimulus nor the individual but instead to the situation (Westbrook and Oliver 1981; Smith and Ellsworth 1985; Scherer 1982; Izard 1977). Recognizing that affect feelings and emotions has long been regarded as important to marketing success (Cohen 1990), models of the satisfaction process have been expanded to consider the role of affect in the satisfaction response (Oliver 1993; Westbrook 1987), since values and priorities of a particular generational cohort are unique relative to other cohorts, satisfaction varies with various attributes of services across generational cohorts (Jackson et al., 2011).

However, little is known about service expectations for diverse market segments such as different generations or how expectations and perceptions of service may vary in different settings thus impacting on the evaluation of the service. Several studies suggest that customers' expectations for services may vary across different contexts in which service is differentiated by customer characteristics (for example, Kwon 2001; Ma and Koh 2001; Churchill et al., 1985; Michaels 1981). Different generational cohorts have different life style which may significantly affect their needs and expectations for services (Ma and Niehm 2006). Thus, according to some researchers, cohort segmentation provides both the stability that age segmentation offers (Steenkamp and Hofstede 2002) and the insights into consumer motivations that value segmentation offers (Jackson et al., 2011; Mitchell 2003; Morgan and Levy 2002).

Additionally, Eastman and Liu (2012) pointed out that generational cohort is a better means to segment the status consumer than other demographic variables. Segmenting people by their generational cohort is an aspect of segmenting consumers based on similar ideas, values and beliefs and has been shown to be valuable for understanding consumer behavior (Brosdahl and Carpenter 2012; Meredith et al., 2007; Dou et al., 2006; Bakewell and Mitchell 2003), and key drivers of marketplace behavior and responding appropriately (Meredith and Schewe 1994). 
The core values and beliefs of the three primary generation groups (Baby Boomers, Generation $\mathrm{X}$, and Generation Y) are used in this study to explain each group's responsiveness to persuasion from customer oriented employees and the various levels of satisfaction.

\section{Baby Boomers}

Boomers, as they are often called, were the result of the persistently high birth rates in between 1945 and the 1960s and, as a result, this generation is densely populated (Becton et al., 2014; Lyons et al.,2007). Baby Boomers key formative years coincided with a rapid increase in trade and economic activities (Schewe and Meredith, 1994) that led to increase in demand for services. Baby Boomer generation prefers face to face communication, (Sherman 2006; Duchscher et al., 2004; Weston 2001; Zust 2001) as they can detect the emotions of the information giver, thereby when a customer oriented employee approaches them, this trait being an emotional interest makes them respond to the efforts made by these employees.

Baby Boomers are also prone to both conspicuous and compensatory consumption (Belk 1986), which suggest that they are susceptible to persuasion and the information obtained from customer oriented employees makes them confident in their choice, and that the evaluation of a service is based on the service received and value of the service. Furthermore, it suggests a high level of materialism, and more specifically the centrality of possessions used to judge the success of oneself and the success of others in a person's life. Therefore, choices made based on the suggestions of customer oriented employees are used to evaluate the service.

Baby Boomers have respect for knowledge (Hughes 2008). This attitude makes them unique to the other groups in that it they value the information provided by customer oriented employees, as being knowledgeable in the sought information. Baby Boomers seek and respond to customer oriented employees when searching for information concerning a service. This generation demonstrate a high job involvement (Jackson et al., 2011), participation with work make them have empathic feelings towards the efforts made by customer oriented employees. They respond positively to employee efforts and their choice decisions are based on what the employees have provided thus affecting the evaluation of the service provided.

Analysts have also viewed this group as highly selective and discerning (Harris et al.2005), members of this cohort group make their choices carefully, and that they recognize the efforts made by customer oriented employees. The information acquired from the employees shape their expectation and evaluation of the service. Baby Boomers demand facts, control and trust, and less easily influenced by their peers (Kasabova and Hain 2014; Appelbaum, Serena and Shapiro 2004). They engage employees whenever they require something or information regarding a service since trust in the service provider and commitment to the service provider is important to them.

Word of mouth from their peers does not affect their decisions but rather from the employees of the service provider. Baby Boomers are open minded experimenters in trying new brands and products (Yang and Jolly 2008; Bernstein 2001), efforts made by customer oriented employees is met openly as they expect variety of information from these employees. Their experimental nature makes the provided information be part of their choice, and thus the choice made affects their evaluation which is based on the service process as well as the interaction with the employees. 
They are often referred to as having values including being idealistic (Strauss and Howe 1991), their aim for perfection makes them want to get more information from customer oriented employees, since they have a strong belief in perfect standards, the information provided is used to arrive at a perfect decision on a selected service provider. This decision impacts on the evaluation of the service process hence satisfaction or dissatisfaction is both from the service process and the information provided by the customer oriented employees. Baby Boomers want instant gratification and are self-indulgent (Moschis 2009) in that, the members of this group want to gain pleasure in the choices that they have made for which the choice of the service was made with the help of customer oriented employees.

Therefore, based on the discussion above the following hypothesis is presented:

H1a: Baby Boomers' responsiveness to persuasion from customer oriented employees will be more than each of the other generational cohorts.

H2a: Baby Boomers' level of satisfaction will be more than each of the other generational cohorts.

\section{Generation $X$}

Generation $X$ are defined by life experiences such as the age of economic uncertainty, recessions, high unemployment, inflation, downsizing, and high divorce rates among their parents (Lyons et al., 2007; Kupperschmidt 2000) the people in this generational group have a skeptical attitude such that any efforts made by customer orientated employees are treated with suspicion, thus decisions made regarding a service is based on their knowledge and other information search for which evaluation of the service is not affected by customer orientation employees, although, they are described as cautious shoppers that seek an honest, straightforward approach (Gardiner et al., 2013; Wuest et al., 2008), they consider all information provided by customer oriented employees and peers as well as other sources since they would like to avoid potential problems that might occur during the interaction with service process.

This group evaluates service process based on the information acquired through various sources and the interaction of customer oriented employees. Generation $\mathrm{X}$ is a reactive generation in that the group responds to the efforts made by customer oriented employees which is contrary to Baby Boomer generation who control the situation by asking directly for the help of customer oriented employees. Furthermore, Generation X is a group with little selfesteem such that they lack confidence in their decision making regarding a service thereby making an inclination towards customer oriented employees for their input to aide in their choice.

Previous research adjudged that Generation X volunteers and joins local organizations in greater numbers, since they freely offer to take part in the organisation, consider information given to them by customer oriented employees as a free offer thus of minor influence when making their decisions, and in extension customer orientation have a minor influence when evaluating the service performance and consequently the satisfaction of the service. This Generation is attributed as having attitudes, values and behaviors of pragmatism, skepticism than any previous generation (Loretto 2011) Thielfoldt and Scheef 2005), they consider the success of a service performance as a practical application of their own making, and therefore they are not obligated to seek for customer oriented employees for assistance or information. Their evaluation of the service process is in part based on the information acquired through different sources and the service provision in totality.

Moreover, this generation go online to find others who share similar interests and perspectives 
(Na"rva"nen et al., 2013b), the information acquired from the peers greatly impact the evaluation of the service process and not in totality from the information acquired through customer oriented employees. Generation X value work life balance (Twenge 2010; Smola and Sutton 2002).They endeavor to strike a balance between the customer-organisation interactions, but they also take positively the input or advice of the customer oriented employees. Furthermore, Davis et al's (2006) research found that Generation X valued job involvement therefore they are empathetic to other customer oriented employees who are focused on the customers. Therefore it is hypothesized as:

H1b: Generation X responsiveness to persuasion from customer oriented employees will be in such a way that it will not be higher than that of Baby Boomers and not lower than that of Generation Y.

H2b: Generation X level of satisfaction will be in such a way that it will not be higher than that of Baby Boomers and not lower than that of Generation Y.

\section{Generation $Y$}

Generation Y are reported to be more individualistic than the other generations (Twenge et al., 2010) which enables them to be unique from the other generational groups by having less emotional interest towards customer orientated employees. They are independent in making their choices regarding a service and their evaluation of the service process is not influenced by the interaction between the employees and the service process. Furthermore, they are said to learn quickly, are very well educated, and are technologically savvy, since they grew up in the era of the internet (Twenge et al., 2010; D'Amato and Herzfeldt 2008; Jenkins 2008; Burke 2004 ). The members in this generation are self-reliant which they rely on their own resources rather than that of customer oriented employees.

Proposal by Schrum et al., (1991) that television programs convey a wealth of information with respect to consumption, and that Generation Y households are around television seven hours a day (Nielsen 1995), which further points out that this generation gathers information required to make a service transaction through other sources rather than from customer oriented employees. This makes them not as responsive as the other generational cohort group, to the efforts made by customer orientated employees since their choices are based on the attributes acquired through their search process, rather than the interaction with customer oriented employees.

Individuals in this segment were typically raised in a secure and goal-driven environment (Howe and Strauss 2003), which gives them the confidence of the choices of services that they have made and thus evaluation is in the totality of the service experience and the service process. Generation $\mathrm{Y}$ is highly attuned and receptive to the environment (Pentecost and Andrews 2010) in that in the current rate of influence made through the social media is enormous and this generation is leading in the use of the social media combined with other mobile device search engines that can be used to acquire information. Customer orientation does not have any influence in their choice decision thus evaluation of the service is not greatly affected by customer oriented employees, but rather on the entire process of the service. They are much more media savvy and less apt to listen to what marketers are saying to them because they loathe being sold to (Hughes 2008), they consider themselves more technologically advanced than the rest of the generational cohort groups and can easily acquire more information without listening to a sales talk which they consider old fashioned and cumbersome, thus making them less responsive to customer oriented employees' persuasion. Evaluation of the service is based on the service process rather than the interaction of customer oriented employees. 
Generation $Y$ is described as anticorporate (Kapner and Cybulski 1997) this shows that they do not believe in the entire system of the service process which may include customer oriented employees. This group would like a system that runs without much interference of human intervention but rather the systems and technology, as their value for customer orientation is minimal. Efforts made by customer oriented employees on this group are lost on them and the presence of employees may lead to being less receptive to customer orientation.

Globalization of society and the marketplace is thought to have had a tremendous impact on their values (Howe et al., 2000) this group engages search engines to find out about the services that they are interested and since services are available globally they tend to use attributes for comparison of similar services across the board. Their evaluation of the service process is based on the attributes and the service process in totality and not through the interaction with the customer oriented employees.

Generation Y seek the input and affirmation of others (Chiang et al., 2014; Schmallegger and Carson 2008; Prensky 2001; Strauss and Howe 2000) this group values the input and information provided by their peers, rating of a specific service from the peers who have experienced the sought service process impacts greatly on their choice decision, and hence evaluation of the service process is based on how other members of the same group have experienced and the service process in totality. This generation respond to learning (Dunne and Lusch 2008; Straus et al., 2006) they would not seek customer oriented employees to find out the expectations of a service process, but rather would like to experience it first-hand so that they can evaluate the service process through this experience. Thus their rating is solely based on the service process.

Generation Y have higher expectations, technology itself may facilitate the impression that they are more self-absorbed (Trzesniewski and Donnellan 2010), their self-centeredness would not allow them to seek assistance from customer oriented employees and that Generation Y are lower in empathic concern, which is the tendency to experience feelings of warmth, compassion and concern for others (Loroz and Helgeson 2013; Davis, 1980). Their overall satisfaction is based on the smoothness of the service systems, since they are at ease with diversity, technology and online communication than previous generations (Choi et al., 2013; Lub et al., 2012; Eisner 2005).

On average they are better educated, more self-assured, techno-literate, materialistic than any other generation (Colucci and Scarpi 2013; Farris et al., 2002; Morton 2001;Merrill 1999; Neuborne and Kerwin 1999) they would not trust the information provided by customer oriented employees and thus their evaluation of the service process is not affected by these employees. This group searches for information regarding the services required, as they are technologically competent, they can engage various search engines in order to arrive at an optimal decision regarding the sought service. Cennamo and Gardner's (2008) study found that Generation Y valued freedom, which shows that they want to make their decisions freely without the persuasion of customer oriented employees. Their choice is based on the attributes of the service such that in case an employee does not perform according to the expectation it does not affect the overall evaluation during a service process, because their choice was not because of how the employees would handle them but because of what they perceived to be of importance when they were making that decision.

Generation Y's extreme confidence, awareness, and individuality, they like convenience and are value oriented individuals, one thing that they will not accept is a hard sell from customer oriented employees. The internet has helped to take the power away from marketers and has 
given it to the consumers. The internet is also a powerful tool for this generation in spreading opinions about products to their peers (Hughes, 2008). When Generation Y is in contact with customer oriented employees, it will not make an influence towards the expected quality of the service because they already know what to expect from a service, which is information provided based on their peers' opinion. Taylor and Cosenza's (2002) research found that Generation Y customers seem to pursue diversity within the group rather than conformity. The attributes of the service is a selling point to this generation and they look for diverse attributes for a specific service rather than conform to what the customer oriented employees to advise them. Thus it is hypothesized that:

H1c: Generation Y responsiveness to persuasion from customer oriented employees will be in such a way that it will be lower than each of the other generational cohorts.

H2c: Generation Y level of satisfaction will be in such a way that it will be lower than each of the other generational cohorts.

\section{METHODS}

\section{Sampling and Data Collection Procedures}

This study used an explanatory research design the study sought to establish the level of responsiveness to persuasion from customer oriented employees and also to establish the different levels of satisfaction of customers across three generational cohort groups. This study was cross-sectional in nature and was carried out in three major international airports in Kenya. Target population was airline customers of different generations (Baby Boomers, Generation X and Generation Y) who have previous experience of an airline service. 600 questionnaires distributed for data collection at the waiting area of the airport. The passengers were asked to recall the most recent air travel experience with a service provider and rate the overall service provided following the service contact. Error associated with this retrospective design was reduced by allowing respondents to select a service of their own choosing, asking for more recent service events and allowing respondents the time needed to complete the questionnaire. It was a wait-and-collect exercise.

\section{Measures}

\section{Customer Orientation}

Customer orientation scale in this study reflected on the degree of consumer's interest towards customer oriented employee efforts. The items measuring customer orientation were adapted from Brown et al., (2002). Customer orientation was measured using ten items on a five-point Likert scale ranging from the lowest being strongly disagree (1) to the highest being strongly agree (5). This scale was originally designed to measure the customer orientation of sales personnel so its wording is slightly reworded to reflect the consumers' perception as well as capture the dimensions.

\section{Customer Satisfaction}

Customer satisfaction was measured using a five item unipolar adjective scale adapted from Westbrook and Oliver (1991). Since satisfaction is considered to be primarily an affective construct, the adjectives used were emotive in nature (Oliver 1997). Respondents were asked to report the degree to which they were happy, pleased, and delighted.

\section{Generational Cohort}

Generational cohort was measured using items developed and utilized specifically for this study. The item is designed to place respondents to their generational groups. 


\section{RESULTS}

The sample population consisted of airline customers of different generations (Baby Boomers, Generation X and Generation Y) with a previous experience of an airline service. A total of 600 questionnaires were distributed; 200 to Baby Boomers, 200 to Generation X and another 200 to Generation Y. The overall response rate was 28\% (56 respondents) for Baby Boomers, 92.0\% (184 respondents) for Generation X and 93.0\% (186 respondents) for Generation Y. Therefore, 426 (71\%) usable questionnaires were returned.

\section{Descriptive Analysis}

\section{Customer Orientation among Airline Passengers}

Customer orientation was measured using ten items distributed across the three dimensions, reflecting on company commitment, customer commitment and customer experience. Respondents were asked to indicate the extent of their agreement with the items. Response scores on each item measuring a variable were summated for each case. The mean scores and standard deviations were then used to examine the respondents' perceptions of customer orientation. In addition skewness and kurtosis statistics were computed in order to examine distribution of responses across each item (see Table 1). The mean scores imply that respondents consistently tended to agree with the existing standards of customer orientation in the airline service. In addition, the skewness and kurtosis suggest that some of the customers in the study sample respond to customer orientation from service employees.

\section{Customer Satisfaction among Airline Passengers}

Customer satisfaction was measured using five items, reflecting on happiness with choice, satisfaction with services, pleased with own decision, suitability of the service to their needs and overall evaluation. Once again, respondents were asked to indicate the extent of agreement or disagreement with the items. Results reveal that on average, passengers are satisfied with the airlines. The satisfaction is consistent among the passengers basing on the small values of the standard deviations (see Table 2).

\section{Tests of Hypothesis}

\section{Customer Orientation among the Generational Cohorts}

Hypothesis $1 \mathrm{a}, \mathrm{b}, \& \mathrm{c}$ were tested using ANOVA. The results in Table 3 show that there is a difference in mean levels of responsiveness to persuasion from customer oriented employees among generational cohorts. Bonferroni post hoc test was further used to explore the three generational cohorts' differences in customer orientation was largest. Results in Table 4 differences in mean response scores across the three generational cohorts exists. The implication is that, the level of responsiveness to persuasion varies across the three generational groups.

\section{Levels of Satisfaction among the Generational Cohorts}

Hypothesis $2 \mathrm{a}, \mathrm{b}$ and $\mathrm{c}$ was tested using ANOVA. The results in Table 5 show that customer satisfaction among the groups is almost similar with a small mean difference in satisfaction levels in each generational cohort. The Bonferroni post hoc test was further used to explore between which three generational cohorts the difference in customer satisfaction was largest. The post hoc test results presented in Table 6 show the difference in customer satisfaction levels vary across the three generational cohort.

\section{DISCUSSION AND MANAGERIAL IMPLICATIONS}

According to generational cohort theory, significant intergenerational differences have been documented among different cohorts (Lu and Alon 2004; Yardley 2003). Despite the prevalent beliefs about the existence of generational differences, empirical research has reported 
somewhat inconsistent results (Kowske, Rasch and Wiley, 2010). Indeed, researchers are still striving to provide more concrete evidence about generational differences around varying constructs by employing more sound methodological approaches to rule out alternative explanations about the generational differences (Park and Gursoy 2014).

Previous research has found disparate generational effects on behavioral measures. Twenge (2010) found that Generation Y is more satisfied than other generations. Contrary to the results of this study, where the findings show that Baby Boomers are more satisfied with the services than any other generational cohort. Generation $Y$ is satisfied less than baby boomers but more than generation X. Generation X's level of satisfaction is the lowest. This could be attributed to the reason that this Generation is attributed as having attitudes, values and behaviors of pragmatism, skepticism than any previous generation (Loretto 2011; Thielfoldt and Scheef 2005). The results show that Generation X is more responsive to persuasion from customer oriented employees than any other group. This may be due to the fact that this group are open minded (Yang and Jolly 2008; Bernstein 2001) and trustworthy (Kasabova and Hain 2014; Appelbaum, Serena, and Shapiro 2004).

This study found differences in responsiveness to persuasion from customer oriented employees as well as different levels of satisfaction among the three generational groups, showing that judgments are made based on their emotions. Further, each group evaluates differently the services that are being offered and thus satisfaction levels are different.

Managers of organisations should be aware that customer orientation is important for the organisation. Therefore it should be embraced at all levels within the organisation. An organisation shall gain a competitive advantage when customer orientation is applied in all sectors, not only providing necessary resources for the company to be oriented but also realize that the customer is also part of this process. Generational cohorts have different attitudes and values that should be addressed differently and separately.

\section{RESEARCH DIRECTIONS}

Future studies should explore whether there are other factors that influence generations among the customers perceptions. A main goal of this study was to examine whether there are mean differences in responsiveness to persuasion from customer oriented employees and expectations are different among the generational cohort groups that are attributable to customer satisfaction.

Findings of this study suggest that some differences do exist in responsiveness and expectations. These findings remind us that, although generational cohort is a meaningful and useful social categorization, one must be careful not to treat the entire generation as the same. Researchers must help service providers become aware of and respond to the nature and benefits of diversity in its various forms, which is increasingly salient in the current patronage.

\section{References}

Arsenault, P. M. (2004), "Validating Generational Differences: A Legitimate Diversity and Leadership issue," Leadership and Organization Development Journal, 25(2): 124-141.

Becton et al., (2014), “Generational Differences in Workplace Behavior,” Journal of Applied Social Psychology, 44, 175-189

Boles, J. S et al., (2001), "An Examination of the Relationships between Retail Work Environments, Salesperson Selling Orientation-Customer Orientation and Job Performance," Journal of Marketing Theory and Practice, 9(3) (Summer,), 1-13 
Bolton et al., (2013), “Understanding Generation Y and Their Use of Social Media: A Review and Research Agenda," Journal of Service Management 24(3), 245-267.

Brach, S. et al, (2013), "A Dyadic Model of Customer Orientation: Mediation and Moderation Effects," British Journal of Management, 1-18.

Brady, M. K. and Cronin, J. J. (2001), "Customer Orientation: Effects on Customer Service Perceptions and Outcome Behaviors," Journal of Service Research, 3, 241.

Brosdahl, D. J. C. and Carpenter, J. M. (2012), "U.S. Male Generational Cohorts: Retail Format Preferences, Desired Retail Attributes Satisfaction and Loyalty," Journal of Retailing and Consumer Services, 19, 545-552.

Brown, Tom J., John C. Mowen, Todd Donavan, and Jane W. Licata (2002), "The Customer Orientation of Service Workers: Personality Trait Effects on Self- and Supervisor Performance Ratings," Journal of Marketing Research, 39 (1), 110-119.

Chen, C.X. et al. (2014), "The Effect of Measurement Timing on the Information Content of Customer Satisfaction Measures," Management Accounting Research.

Cennamo, L., \& Gardner, D. (2008), “Generational differences in work values, outcomes and person-organization values fit," Journal of Managerial Psychology, 23, 891-906.

Chiang, L. et al, (2014), "A Comparative Study of Generational Preferences for Trip-Planning Resources: A Case Study of International Tourists to Shanghai" Journal of Quality Assurance in Hospitality and Tourism, 15, 78-99.

Choi, Y. G. et al, (2013), "Effects of attitudes vs. experience of workplace fun on employee behaviors Focused on Generation Y in the hospitality industry," International Journal of Contemporary Hospitality Management, 25(3), 410-427.

Colucci, M. and Scarpi, D. (2013), “Generation Y: Evidences from the Fast-Fashion Market and Implications for Targeting" Journal of Business Theory and Practice, 1(1), March

Deng, Z. et al, (2010), "Understanding Customer Satisfaction and Loyalty: An Empirical Study of Mobile Instant Messages in China" International Journal of Information Management, 30 289-300.

Delcourt, C. et al, (2013), "Effects of Perceived Employee Emotional Competence on Customer Satisfaction and Loyalty the Mediating Role of Rapport," Journal of Service Management, 24(1), 5-24.

Eastman, J. K. and Liu, F. (2012), “The impact of generational cohorts on status consumption: an exploratory look at generational cohort and demographics on status consumption" Journal of Consumer Marketing, 29(2) 93-102.

Grönroos, C. (1998), "Marketing Services: The Case of a Missing Product," Journal of Business and Industrial Marketing, 13 (4/5), 322-338.

Harris, E. G. et al., (2005), "Re-examining Salesperson Goal Orientations: Personality Influencers, Customer Orientation, and Work Satisfaction" Journal of the Academy of Marketing Science, 33, 19.

Hughes, A. (2008), "Y and How. Strategies for Reaching the Elusive Generation Y Consumer" Honors College Theses Paper 74 (available at http://digitalcommons.pace.edu/honorscollegetheses/74)

Jackson, V. et al., (2011), "Mall Attributes and Shopping Value: Differences by Gender and Generational Cohort," Journal of Retailing and Consumer Services, 18 1-9.

Jones, Thomas, and Earl Sasser (1995), "Why Satisfied Customers Defect," Harvard Business Review, 73 (6), $88-$ 100.

Justin Kruger and David Dunning (1999), "Unskilled and Unaware of It: How Difficulties in Recognizing One's Own Incompetence Lead to Inflated Self-Assessments", Journal of Personality and Social Psychology, 77( 6), 121-1134

Kasabova, E. and Hain, T. (2014), "Cross-generational perceptions and reactions during service recovery," The Service Industries Journal, 34(1), 71-87.

Kohli, A. K. and Jaworski, B. J. (1990), "Market Orientation: The Construct, Research Propositions, and Managerial Implications" Journal of Marketing, 54(2) (April), 1-18.

Kowske, B. J., Rasch, R., \& Wiley, J. (2010), “Millennials' (lack of) attitude problem: an empirical examination of generational effects on work attitudes," Journal of Business and Psychology, 25(2), 265-279.

Leuty, M. E., and Hansen, J.-I. C. (2014), "Teasing Apart the Relations between Age, Birth Cohort, and Vocational Interests," Journal of Counseling Psychology. March 24

Lois A. Mohr and Mary Jo Bitner (1995), "The role of employee effort in satisfaction with service transactions" 
Journal of Business Research, 32(3), 239-252.

Loroz, P. S. and Helgeson, J. G. (2013), "Boomers and Their Babies: An Exploratory Study Comparing Psychological Profiles and Advertising Appeal Effectiveness across Two Generations," Journal of Marketing Theory and Practice, 21(3) (summer), 289-306.

Ma, Y. J and Niehm, L. S. (2006), "Service Expectations of Older Generation Y Customers. An Examination of Apparel Retail Settings," Managing Service Quality, 16 (6), 620-640.

Machleit, K. A. and Eroglu, S. A. (2000), "Describing and Measuring Emotional Response to Shopping Experience," Journal of Business Research, 49, 101-111.

Meredith, Geoffrey and Schewe, Charles D. (1994), "The Power of Cohorts",

American Demographics, December, 22-31.

Na"rva"nen, E.et al (2013b), "Online Lifestyle Consumption Community Dynamics: A Practice-Based Analysis," Journal of Consumer Behaviour, 12, 358-369.

Pallas, F. (2014), "Allocation of Resources to Customer Satisfaction and Delight Based on Utilitarian and Hedonic Benefits," Journal of Research in Marketing, 2 (1) 106-112.

Paul M. Arsenault (2004), "Validating generational differences: A legitimate diversity and leadership issue", Leadership \& Organization Development Journal, 25(2), 124 - 141

Parasuraman, A. et al., (1992), "Perceived Service Quality as a Customer-Based Performance Measure: An Empirical Examination of Organizational Barriers Using an Extended Service Quality Model" Human Resource Management, 30(3), (Fall), 335-364.

Park, J. and Gursoy, D. (2014), "Generation Effect on the Relationship between Work Engagement, Satisfaction, and Turnover Intention among US Hotel Employees" School of Hospitality Business Management, College of Business, Washington State University.

Parry, E., and Urwin, P. (2011), "Generational differences in work values: A review of theory and evidence," International Journal of Management Reviews, 13, 79-96.

Patterson, P.G et al (1997), "Modeling the Determinants of Customer Satisfaction for Business-to-Business Professional Service" Journal of the Academy of Marketing Science 25 (1), 4-17.

Pentecost, R. and Andrews, L. (2010), "Fashion Retailing and the Bottom Line: The Effects of Generational Cohorts, Gender, Fashion Fanship, Attitudes and Impulse Buying On Fashion Expenditure," Journal of Retailing and Consumer Services, 17, 43-52.

Pourtois, G. et al., (2013), "Brain Mechanisms for Emotional Influences on Perception and Attention: What Is Magic and What Is Not," Biological Psychology, 92, 492-512.

Robert A. Westbrook and Richard L. Oliver (1981),"Developing Better Measures of Consumer Satisfaction: Some Preliminary Results", Advances in Consumer Research 8, 94-99.

Ruey-Jer "Bryan" Jean, Zhiqiang Wang , Xiande Zhao, Rudolf R. Sinkovics , (2016) "Drivers and customer satisfaction outcomes of CSR in supply chains in different institutional contexts: A comparison between China and Taiwan", International Marketing Review, 33(4), 514 - 529.

Sarah Gardiner , Debra Grace and Ceridwyn King (2013), "Challenging the use of generational segmentation through understanding self-identity", Marketing Intelligence \& Planning, 31( 6), 639 - 653.

Sherman, R. (2006), "Leading a Multigenerational Nursing Workforce: Issues, Challenges and Strategies," Journal of Issues in Nursing, 11(2), 13-13.

Strauss, W. and Howe, N. (1997), The Fourth Turning, Broadway Books, New York, NY

Howe, N., \& Strauss, W. 2000. Millennials rising: The next great generation. New York: Vintage Books.

Ta-Wei Tang, (2014), "Becoming an Ambidextrous Hotel: The Role of Customer Orientation" International Journal of Hospitality Management, 39, 1-10.

Jean M. Twenge (2010), "A review of the empirical evidence on generational differences in work attitudes," Journal of Business and Psychology, 25(2), 201-210.

Trzesniewski, K. H., and Donnellan, M. B. (2010), "Rethinking "Generation Me": A Study of Cohort Effects from 1976-2006," Perspectives on Psychological Science, 5(1), 58-75. 
Valenzuela, L. M. et al (2010), "Impact of Customer Orientation, Inducements and Ethics on Loyalty to the Firm: Customers' Perspective," Journal of Business Ethics, 93(2) May, 277-291.

Veloutsou, C. et al, (2005), "Measuring Transaction-Specific Satisfaction in Services. Are the Measures Transferable Across Cultures?” European Journal of Marketing, 39(5/6), 606-628.

Wansoo Kim (2009), “Customers' Responses to Customer Orientation of Service Employees in Full-Service Restaurants: A Relational Benefits Perspective," Journal of Quality Assurance in Hospitality \& Tourism, 10(3), 153174.

Westbrook, R. A. (1987), “Product/Consumption-Based Affective Responses and Post purchase Processes,” Journal of Marketing Research, 24(3) (Aug.), 258-270.

Xueming Luo and Christian Homburg (2007), "Neglected Outcomes of Customer Satisfaction," Journal of Marketing, April, 71( 2) 133-149.

Yang, K. and Jolly, L. D. (2008), "Age Cohort Analysis in Adoption of Mobile Data Services: Gen Xers versus Baby Boomers," Journal of Consumer Marketing.25 (5) 272-280.

Zafar M. et al., (2012), "Service Quality, Customer Satisfaction and Loyalty: An Empirical Analysis of Banking Sector in Pakistan," Information Management and Business Review, 4(3), (Apr.) 159-167.

Table 1

Perceptions of Customer Orientation among Airline Passengers

\begin{tabular}{|c|c|c|c|c|c|c|}
\hline Response Items & Minimum & $\begin{array}{l}\text { Maximu } \\
\text { m }\end{array}$ & Mean & $\begin{array}{l}\text { Std. } \\
\text { Deviation }\end{array}$ & Skewness & Kurtosis \\
\hline Help customers & 1.00 & 5.00 & 3.73 & 1.08 & -.54 & -.48 \\
\hline Perform as promised & 1.00 & 5.00 & 3.79 & .92 & -.63 & .34 \\
\hline Physical facilities & 1.00 & 5.00 & 3.81 & .99 & -.62 & -.03 \\
\hline Convey confidence & 1.00 & 5.00 & 3.85 & .98 & -.60 & -.24 \\
\hline Individualised attention & 1.00 & 5.00 & 3.93 & 1.01 & -.63 & -.39 \\
\hline Employees talk about their service & 1.00 & 5.00 & 3.10 & .93 & -.81 & .24 \\
\hline In making employees happy & 1.00 & 5.00 & 4.06 & .79 & -.58 & .25 \\
\hline Enjoy responding quickly & 2.00 & 5.00 & 4.10 & .74 & -.60 & .29 \\
\hline Empathy on employees & 2.00 & 5.00 & 4.13 & .74 & -.57 & .13 \\
\hline Enjoy being served & 1.00 & 5.00 & 4.17 & .72 & -.73 & .95 \\
\hline $\begin{array}{l}\text { Valid N (listwise) } \\
\text { Composite mean }\end{array}$ & 415 & & 3.87 & .89 & & \\
\hline
\end{tabular}

Table 2

Satisfaction among Airline Passengers

\begin{tabular}{lllllll}
\hline Response Items & \multirow{2}{*}{ Minimum } & Maximum & Mean & $\begin{array}{l}\text { Std. } \\
\text { Deviation }\end{array}$ & Skewness & Kurtosis \\
\hline Satisfied with services & 1.00 & 5.00 & 4.10 & .74 & -.91 & 1.68 \\
Happy with choice & 1.00 & 5.00 & 4.11 & .80 & -.88 & .95 \\
Pleased with decision & 1.00 & 5.00 & 4.08 & .82 & -.84 & .76 \\
For travel needs & 1.00 & 5.00 & 4.08 & .82 & -.88 & .84 \\
Overall evaluation & 1.00 & 5.00 & 4.05 & .85 & -1.16 & 2.07 \\
Composite Mean & & & 4.08 & .81 & & \\
\hline
\end{tabular}


Table 3

Responsiveness to Persuasion from Customer Oriented Employees

\begin{tabular}{|c|c|c|c|c|c|c|c|c|}
\hline & \multirow[b]{2}{*}{$\mathrm{N}$} & \multirow[b]{2}{*}{ Mean } & \multirow[b]{2}{*}{$\begin{array}{l}\text { Std. } \\
\text { Deviation }\end{array}$} & \multirow[b]{2}{*}{ Std. Error } & \multicolumn{2}{|c|}{$\begin{array}{l}95 \% \text { Confidence } \\
\text { Interval for Mean } \\
\end{array}$} & \multirow[b]{2}{*}{ Min } & \multirow[b]{2}{*}{$\operatorname{Max}$} \\
\hline & & & & & $\begin{array}{l}\text { Lower } \\
\text { Bound }\end{array}$ & $\begin{array}{l}\text { Upper } \\
\text { Bound }\end{array}$ & & \\
\hline Baby Boomers & 56 & 40.25 & 4.42 & .591 & 39.07 & 41.44 & 30.00 & 50.00 \\
\hline Generation X & 176 & 38.95 & 5.22 & .393 & 38.17 & 39.73 & 20.00 & 49.00 \\
\hline Generation Y & 183 & 39.92 & 4.74 & .350 & 39.22 & 40.61 & 28.00 & 50.00 \\
\hline Total & 415 & 39.55 & 4.93 & .242 & 39.07 & 40.02 & 20.00 & 50.00 \\
\hline
\end{tabular}

Note: Min=Minimum; Max=Maximum

Table 4

Bonferroni Post Hoc Multiple Comparisons among Generational Cohorts

\begin{tabular}{|c|c|c|c|c|c|c|c|}
\hline \multirow[b]{2}{*}{ (I) Birth year } & \multirow[b]{2}{*}{ (J) Birth year } & \multirow[b]{2}{*}{$\begin{array}{l}\text { Mean } \\
(\mathrm{I}-\mathrm{J})\end{array}$} & \multirow[b]{2}{*}{ Difference } & & & \multirow{2}{*}{$\begin{array}{l}95 \% \\
\text { Interval } \\
\text { Lower } \\
\text { Bound }\end{array}$} & Confidence \\
\hline & & & & Std. Error & Sig. & & $\begin{array}{l}\text { Upper } \\
\text { Bound }\end{array}$ \\
\hline \multirow[t]{2}{*}{ Baby Boomers } & Generation X & 1.301 & & .753 & .255 & -.510 & 3.112 \\
\hline & Generation Y & .337 & & .750 & 1.000 & -1.465 & 2.140 \\
\hline \multirow[t]{2}{*}{ Generation X } & Baby Boomers & -1.301 & & .753 & .255 & -3.112 & .510 \\
\hline & Generation Y & -.964 & & .518 & .191 & -2.210 & .282 \\
\hline \multirow[t]{2}{*}{ Generation Y } & Baby Boomers & -.337 & & .750 & 1.000 & -2.140 & 1.465 \\
\hline & Generation X & .964 & & .518 & 191 & -.282 & 2.210 \\
\hline
\end{tabular}

Table 5

Comparison of Customer Satisfaction among Generational Cohort

\begin{tabular}{|c|c|c|c|c|c|c|c|c|}
\hline & \multirow[b]{2}{*}{$\mathrm{N}$} & \multirow[b]{2}{*}{ Mean } & \multirow[b]{2}{*}{$\begin{array}{l}\text { Std. } \\
\text { Deviation }\end{array}$} & \multirow[b]{2}{*}{ Std. Error } & \multicolumn{2}{|c|}{$\begin{array}{l}\text { 95\% Confidenc } \\
\text { Interval for Mean }\end{array}$} & \multirow[b]{2}{*}{ Min } & \multirow[b]{2}{*}{ Max } \\
\hline & & & & & $\begin{array}{l}\text { Lower } \\
\text { Bound }\end{array}$ & $\begin{array}{l}\text { Upper } \\
\text { Bound }\end{array}$ & & \\
\hline Baby Boomers & 56 & 21.11 & 2.95 & .395 & 20.32 & 21.90 & 11.00 & 25.00 \\
\hline Generation X & 176 & 20.35 & 3.02 & .228 & 19.90 & 20.80 & 11.00 & 25.00 \\
\hline Generation Y & 183 & 20.27 & 3.62 & .268 & 19.74 & 20.80 & 7.00 & 25.00 \\
\hline Total & 415 & 20.42 & 3.29 & .167 & 20.10 & 20.73 & 7.00 & 25.00 \\
\hline
\end{tabular}

Note: Min=Minimum; Max=Maximum 
Table 6

Bonferroni Post Hoc Multiple Comparisons among Generational Cohorts

\begin{tabular}{|c|c|c|c|c|c|c|}
\hline & & \multirow{2}{*}{$\begin{array}{l}\text { Mean } \\
\text { Difference } \\
(\mathrm{I}-\mathrm{J})\end{array}$} & & & $\begin{array}{l}95 \% \\
\text { Interval } \\
\end{array}$ & Confidence \\
\hline (I) Cohort & (J) Cohort & & \multicolumn{2}{|c|}{ Std. Error Sig. } & $\begin{array}{l}\text { Lower } \\
\text { Bound }\end{array}$ & $\begin{array}{l}\text { Upper } \\
\text { Bound }\end{array}$ \\
\hline \multirow[t]{2}{*}{ Baby Boomers } & Generation X & .761 & .505 & .398 & -.453 & 1.974 \\
\hline & Generation Y & .840 & .502 & .287 & -.368 & 2.047 \\
\hline \multirow[t]{2}{*}{ Generation X } & Baby Boomers & -.761 & .505 & .398 & -1.974 & .453 \\
\hline & Generation Y & .079 & .347 & 1.000 & -.756 & .914 \\
\hline \multirow[t]{2}{*}{ Generation Y } & Baby Boomers & -.840 & .502 & .287 & -2.047 & .368 \\
\hline & Generation X & -.079 & .347 & 1.000 & -.914 & .756 \\
\hline
\end{tabular}

